\title{
KUALITAS SPERMATOZOA TIKUS WISTAR (Rattus norvegicus) SETELAH PEMAPARAN OBAT NYAMUK ELEKTRIK BERBAHAN AKTIF TRANSFLUTRIN
}

\author{
${ }^{1}$ Elia \\ ${ }^{2}$ Lusiana Satiawati \\ ${ }^{2}$ Janette. M. Rumbajan \\ ${ }^{1}$ Kandidat Skripsi Fakultas Kedokteran Universitas Sam Ratulangi \\ ${ }^{2}$ Bagian Biologi Fakultas Kedokteran Universitas Sam Ratulangi Manado \\ Email: e.elia11_289@yahoo.com
}

\begin{abstract}
Transflutrin $\left(\mathrm{C}_{15} \mathrm{H}_{12} \mathrm{CL}_{2} \mathrm{~F}_{4} \mathrm{O}_{2}\right)$ is an active substance, a derivative of pyrethroid compounds found in electric mosquito repellent. Previous studies showed that group of pyrethroid insecticides can play a role in causing histological changes in testes, decreased testicular weight and reducing diameter of seminiferous tubules. The purpose of this study was to determine the quality of wistar male sperm that are exposed to electric mosquito repellent with transflutrin as active ingredients. This study is experimental with completely randomized design, conducted for 52 days by using eight wistar which consists of two wistar as controls $\mathrm{P}_{0}$, 3 wistar with exposure to electric insect repellent for 8 hours/day $\left(\mathrm{P}_{1}\right)$, and 3 other wistar for 12 hours/day $\left(\mathrm{P}_{2}\right)$. The results of this study, the concentration of spermatozoa in the treatment group $\mathrm{P}_{1}$ and $\mathrm{P}_{2}$ respectively at $54.17 \times 10^{6}$ spermatozoa $/ \mathrm{ml}$ and $45.5 \times 10^{6}$ spermatozoa / $\mathrm{ml}$, in the control group P0 of $59.25 \times 10^{6}$ spermatozoa $/ \mathrm{ml}$. Abnormal sperm motility in $\mathrm{P}_{1}$ and $\mathrm{P}_{2}$ is $40 \%$ and $35 \%$, at $\mathrm{P}_{0}$ is $45 \%$. Morphologically normal spermatozoa in $\mathrm{P}_{1}$ and $\mathrm{P}_{2}$ is $49 \%$ and $78 \%$. It can be concluded that exposure to electric mosquito repellent with transflutrin as active ingredients causes a decrease in sperm quality.
\end{abstract}

Keywords: electronic mosquito repellents, pyrethroid, transflutrin, male wistar rats, sperm quality

\begin{abstract}
Abstrak: Transflutrin $\left(\mathrm{C}_{15} \mathrm{H}_{12} \mathrm{CL}_{2} \mathrm{~F}_{4} \mathrm{O}_{2}\right)$ adalah zat aktif yang merupakan senyawa turunan dari pyrethroid dalam obat nyamuk elektrik. Hasil penelitian sebelumnya menunjukkan bahwa insektisida golongan pyrethroid dapat menyebabkan perubahan histologis testis, menurunnya berat testis dan berkurangnya diameter tubulus seminiferus. Tujuan dari penelitian ini adalah untuk mengetahui kualitas spermatozoa wistar jantan (Rattus norvegicus) yang dipapari obat nyamuk elektrik berbahan aktif transflutrin. Penelitian ini bersifat eksperimental dengan rancangan acak lengkap yang dilakukan selama 52 hari dengan menggunakan sampel sebanyak 8 wistar yang terdiri atas 2 wistar sebagai kontrol $\left(\mathrm{P}_{0}\right)$, 3 wistar dengan pemaparan obat nyamuk selama 8 jam/hari $\left(\mathrm{P}_{1}\right)$, dan 3 wistar lainnya selama 12 jam/hari $\left(\mathrm{P}_{2}\right)$. Hasil dari penelitian ini didapatkan konsentrasi spermatozoa pada kelompok perlakuan $\mathrm{P}_{1}$ dan $\mathrm{P}_{2}$ secara berurutan sebesar $54,17 \times 10^{6}$ spermatozoa/ml dan $45,5 \times 10^{6}$ spermatozoa/ml, pada kelompok kontrol $\mathrm{P}_{0}$ sebesar 59,25 x $10^{6}$ spermatozoa/ml. Motilitas spermatozoa normal pada $\mathrm{P}_{1}$ dan $\mathrm{P}_{2}$ adalah $40 \%$ dan $35 \%$, pada $\mathrm{P}_{0}$ adalah $45 \%$. Morfologi abnormal spermatozoa pada $\mathrm{P}_{1}$ dan $\mathrm{P}_{2}$ adalah $49 \%$ dan $78 \%$. Berdasarkan hasil penelitian ini dapat disimpulkan bahwa pemaparan obat nyamuk elektrik berbahan aktif transflutrin menyebabkan penurunan kualitas spermatozoa.
\end{abstract}

Kata kunci: obat nyamuk elektrik, pyrethroid, transflutrin, tikus wistar jantan, kualitas spermatozoa 
Elia, Satiawati, Rumbajan: Kualitas spermatozoa tikus...

Transflutrin merupakan salah satu golongan pyrethroid yang memiliki rumus kimia $\mathrm{C}_{15} \mathrm{H}_{12} \mathrm{CL}_{2} \mathrm{~F}_{4} \mathrm{O}_{2} .{ }^{1}$ Zat ini banyak digunakan sebagai racun pembasmi nyamuk yang memiliki resiko merusak kesehatan. ${ }^{2}$

Pyrethroid yang masuk ke dalam tubuh secara inhalasi dalam waktu yang lama, selain dapat menyebabkan gangguan pada paru-paru juga dapat mengakibatkan iritasi kulit, mata, dan asma, serta menyebabkan hati tidak mampu untuk melakukan detoksifikasi secara sempurna.,3 Hal ini mengakibatkan munculnya metabolit sekunder yang dapat bertindak sebagai radikal bebas,selanjutnya radikal bebas inimengikuti peredaran darah menuju keseluruh tubuh termasuk testis yang akan menyebabkan kerusakan. ${ }^{4}$ Bila testis rusak, spermatogenesis akan terganggu dan pada akhirnya akan mempengaruhi kualitas spermatozoa yang dihasilkan. ${ }^{5}$

Hasil penelitian sebelumnya menunjukkan bahwa obat nyamuk inhalasi golongan pyrethroid yaitu tetramethrin dapat menyebabkan perubahan histologi testis, menurunnya berat testis dan berkurangnya diameter tubulus seminiferus. ${ }^{5}$ Gangguan pada testis ini mengakibatkan spermatogenesis terhambat sehingga terjadi penurunan kualitas spermatozoa, yaitu motilitas dan konsentrasi spermatozoa. ${ }^{5}$ Pemaparan turunan pyrethroid lainnya yaitu alletrin mengakibatkan penurunan kualitas spermatozoa yaitu konsentrasi, motilitas, dan morfologi tikus wistar. $^{4}$ Pemaparan permethrin menyebabkan penurunan konsentrasi dan motilitas spermatozoa tikus. $^{6}$

Bermula dari hasil penelitian yang menyebutkan bahwa obat nyamuk inhalasi golongan pyrethroid tersebut diatas dapat menyebabkan gangguan pada kualitas spermatozoa, maka penulis tertarik untuk melakukan penelitian lebih lanjut pada obat nyamuk inhalasi golongan pyrethroid jenis lain yaitu transflutrin. Apakah obat nyamuk elektrik berbahan aktif transflutrin dapat mempengaruhi spermatogenesis dengan indikator kualitas spermatozoa tikus wistar jantan.

\section{METODE PENELITIAN}

Bentuk penelitian ini adalah penelitian eksperimental dengan rancangan acak lengkap (completely randomized design).

Penelitian dilakukan selama 2 bulan dari bulan Oktober - Desember 2014. Pemaparan obat nyamuk elektrik berbahan aktif transflutrin terhadap tikus wistar jantan dilakukan selama 52 hari dari tanggal 16 November sampai tanggal 29 Desember 2014. Penelitian bertempat di Laboratorium Biologi Fakultas Kedokteran Universitas Sam Ratulangi.

Tikus wistar yang digunakan dalam penelitian ini adalah sebanyak 8 ekor yang terdiri atas 2 ekor tikus wistar tanpa pemaparan sebagai kontrol $\left(\mathrm{P}_{0}\right), 3$ ekor tikus wistar dengan pemaparan obat nyamuk elektrik berbahan aktif transflutrin selama 8 jam $\left(\mathrm{P}_{1}\right)$, serta 3 ekor tikus wistar dengan pemaparan obat nyamuk elektrik berbahan aktif transflutrin selama 12 jam $\left(\mathrm{P}_{2}\right)$.

Alat dan bahan yang digunakan dalam penelitian ini adalah tikus wistar sebanyak 8 ekor, makanan tikus berupa pelet, minuman tikus yaitu air ledeng, obat nyamuk elektrik yang mengandung transflutrin, kandang pemeliharaan tikus wistar kontrol berjumlah satu, kandang perlakuan berjumlah enam berukuran $31 \mathrm{~cm} \times 28 \mathrm{~cm} \times 9 \mathrm{~cm}$, peralatan untuk perlakuan tikus wistar yaitu karton, kabel kombinasi, colokan obat nyamuk elektrik, bilik hitung hemasitometer Improved Neubauer, dissecting kit, objek gelas, gelas penutup, pipet tetes, cawan petri, kapas, counter (alat penghitung), mikroskop listrik, kamera digital untuk fotomikrografi dan timbangan digital.

\section{Pengambilan Sampel}

Terminasi dan analisis kualitas spermatozoa dilakukan setelah perlakuan yaitu paparan obat nyamuk elektrik berbahan aktif transflutrin diberikan pada tikus wistar selama 52 hari.

Hewan coba diterminasi kemudian 
dibedah menggunakan disecting kit untuk mengambil organ testis dan cauda epididimis. Cauda epididimis dipisahkan dari testis dengan cara memotong bagian proksimal corpus epididimis dan bagian distal vas deferens. Selanjutnya, cauda epididimis dimasukkan ke dalam cawan petri yang berisi $1 \mathrm{ml}$ NaCL 0,9\%, kemudian cauda epididimis dipotongpotong sampai halus dan diaduk dengan NaCL 0,9\% sehingga terbentuk suspensi spermatozoa.

\section{Pengamatan Sampel}

\section{a. Konsentrasi Spermatozoa}

Suspensi spermatozoa yang telah diperoleh terlebih dahulu dibuat homogen dengan cara digetarkan dengan tangan atau diaduk dengan hati-hati dengan gelas pengaduk. Suspensi spermatozoa dihisap sebanyak 0,005 $\mathrm{ml}$ sampel, setelah itu cairan pengencer dihisap dalam pipet sampai tanda 1,01. Suspensi spermatozoa diteteskan dari pipet, tepat pada pinggir gelas penutup itu hingga menyebar. Bilik hitung hemasitometer Improved Neubauer diletakkan dibawah mikroskop dengan perbesaran 400 kali. Kemudian konsentrasi spermatozoa pada bidang A, B, C, D dihitung. Total perhitungan disubsitusi

Konsentrasi spermatozoa $=(\mathrm{N}$ $1+2+3+4) \times 50.000 \mathrm{sperma} / \mathrm{mL}$

dalam rumus penentuan konsentrasi spermatozoa dalam ml suspensi sekresi cauda epididimis sebagai berikut :

$\mathrm{N}$ = Jumlah total spermatozoa yang dihitung pada kotak A, B, C, D. ${ }^{7}$

\section{b. Motilitas Spermatozoa}

\section{Suspensi}

spermatozoa

diteteskan pada gelas objek menggunakan pipet tetes dan ditutup menggunakan gelas penutup. Kemudian gerakan-gerakan spermatozoa diamati dibawah mikroskop dengan perbesaran 400 kali. Empat sampai enam lapangan pandang diperiksa untuk mendapatkan 100

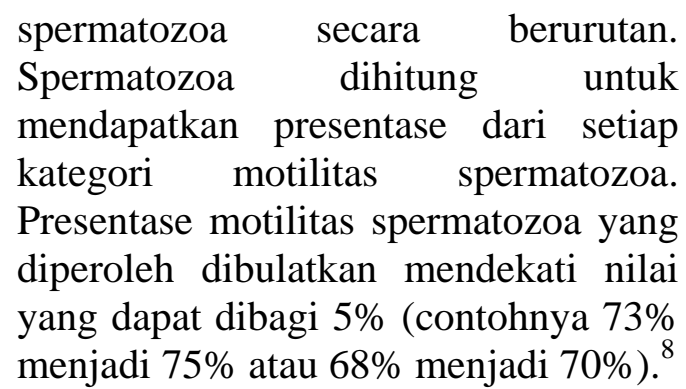

Kategori motilitas spermatozoa adalah sebagai berikut:

i. Kategori A: gerakan spermatozoa maju lurus dan cepat (progresif).

ii. KategoriB : gerakan spermatozoa belok-belok, sulit maju lurus/lambat (nonprogresif).

iii. Kategori C : spermatozoa diam atau tidak tampak bergerak (immotil).

Presentase motilitas spermatozoa yang normal adalah presentase dari kategori A dan B. Presentase motilitas spermatozoa yang abnormal adalah presentase dari kategori C. ${ }^{7}$

\section{c. Morfologi Spermatozoa}

Suspensi spermatozoa diteteskan diatas gelas objek, kemudian dibuat preparat apus dan dikeringkan di udara. Fiksasi preparat apus dilakukan dengan metanol selama 5 menit. Pewarnaan dilakukan dengan safranin selama 5 menit. Preparat dicuci dengan akuades dan dikeringkan, kemudian diamati dibawah mikroskop dengan perbesaran 400 kali untuk mengetahui morfologi spermatozoa tikus wistar. Presentase morfologi spermatozoa normal dan abnormal kemudian dihitung. ${ }^{9}$

\section{HASIL PENELITIAN DAN BAHASAN}

Tikus wistar (Rattus norvegicus) yang digunakan dalam penelitian ini adalah sebanyak 8 ekor tikus wistar jantan. Dua ekor tikus wistar digunakan sebagai kontrol $\left(\mathrm{P}_{0}\right), 3$ ekor tikus wistar digunakan pada perlakuan pemaparan obat nyamuk elektrik berbahan aktif transflutrin selama 8 jam 
$\left(\mathrm{P}_{1}\right)$, serta 3 ekor tikus wistar digunakan pada perlakuan pemaparan obat nyamuk elektrik berbahan aktif transflutrin selama 12 jam $\left(\mathrm{P}_{2}\right)$. Perlakuan pemaparan obat nyamuk elektrik berbahan aktif transflutrin ini dilakukan setiap hari selama satu siklus spermatogenesis yaitu 52 hari.

Tabel 1. Hasil analisis rata-rata konsentrasi spermatozoa tikus wistar

\begin{tabular}{cc}
\hline Kelompok sampel & $\begin{array}{c}\text { Rata-rata konsentrasi } \\
\text { spermatozoa }\left(\times 10^{6}\right)\end{array}$ \\
\hline $\mathrm{P}_{0}$ & 59,25 \\
$\mathrm{P}_{1}$ & 54,17 \\
$\mathrm{P}_{2}$ & 45,5 \\
\hline
\end{tabular}

Keterangan: $\mathrm{P}_{0}$, kontrol (tanpa perlakuan); $\mathrm{P}_{1}$, pemaparan obat nyamuk elektrik berbahan aktif transflutrin selama 8 jam; $\mathrm{P}_{2}$, pemaparan obat nyamuk berbahan aktif transflutrin selama 12 jam.

Hasil ini menunjukkan kecenderungan penurunan rata-rata konsentrasi spermatozoa tikus wistar setelah diberikan pemaparan obat nyamuk elektrik berbahan aktif transflutrin dibandingkan dengan tikus wistar kontrol. Semakin lama pemaparan obat nyamuk elektrik berbahan aktif transflutrin, semakin terjadi kecenderungan penurunan konsentrasi spermatozoa tikus wistar.

Tabel 2. Hasil analisis rata-rata motilitas spermatozoa tikus wistar

\begin{tabular}{cccc}
\hline \multirow{2}{*}{$\begin{array}{c}\text { Kelompok } \\
\text { Sampel }\end{array}$} & \multicolumn{3}{c}{ Motilitas Spermatozoa (\%) } \\
& Kategori & Kategor & Kategori \\
& $\mathrm{A}$ & i B & $\mathrm{C}$ \\
\hline $\mathrm{P}_{0}$ & 20 & 25 & 55 \\
$\mathrm{P}_{1}$ & 2 & 35 & 60 \\
$\mathrm{P}_{2}$ & 0 & 35 & 65 \\
\hline
\end{tabular}

Keterangan: $\mathrm{P}_{0}$, kontrol (tidak diberi perlakuan); $\mathrm{P}_{1}$, pemaparan obat nyamuk elektrik selama 8 jam; $P_{2}$, pemaparan obat nyamuk selama 12 jam.

Hasil ini menunjukkan kecenderungan kenaikan rata-rata motilitas spermatozoa tikus wistar kategori $\mathrm{C}$ setelah diberikan pemaparan obat nyamuk elektrik berbahan aktif transflutrin $\left(\mathrm{P}_{1}\right.$ dan $\left.\mathrm{P}_{2}\right)$ dibandingkan dengan tikus wistar kontrol $\left(\mathrm{P}_{0}\right)$.

Tabel 3. Hasil analisis rata-rata morfologi normal spermatozoa tikus wistar

\begin{tabular}{cc}
\hline $\begin{array}{c}\text { Kelompok } \\
\text { Sampel }\end{array}$ & $\begin{array}{c}\text { Rata-rata morfologi normal } \\
\text { Spermatozoa (\%) }\end{array}$ \\
\hline P0 & 75 \\
P1 & 51 \\
P2 & 22 \\
\hline
\end{tabular}

Keterangan: $\quad P_{0}, \quad$ kontrol (tidak diberi perlakuan); $\quad \mathrm{P}_{1}$, pemaparan obat nyamuk elektrik selama 8 jam; $\mathrm{P}_{2}$, pemaparan obat nyamuk selama 12 jam.

$$
\text { Hasil ini menunjukkan }
$$

kecenderungan penurunan rata-rata konsentrasi spermatozoa tikus wistar setelah diberikan pemaparan obat nyamuk elektrik dibandingkan dengan tikus wistar kontrol. Semakin lama pemaparan obat nyamuk elektrik berbahan aktif transflutrin maka semakin terjadi penurunan rata-rata morfologi normal spermatozoa tikus wistar.

Tabel 4. Hasil analisis rata-rata morfologi abnormal spermatozoa tikus wistar

\begin{tabular}{cc}
\hline $\begin{array}{c}\text { Kelompok } \\
\text { Sampel }\end{array}$ & $\begin{array}{c}\text { Rata-rata morfologi abnomal } \\
\text { spermatozoa (\%) }\end{array}$ \\
\hline P0 & 25 \\
P1 & 49 \\
P2 & 78 \\
\hline
\end{tabular}

Keterangan: $\quad \mathrm{P}_{0}, \quad$ kontrol (tidak diberi perlakuan); $\mathrm{P}_{1}$, pemaparan obat nyamuk elektrik selama 8 jam; $P_{2}$, pemaparan obat nyamuk selama 12 jam.

Hasil ini menunjukkan lamanya pemaparan obat nyamuk elektrik berbahan aktif transflutrin maka semakin terjadi penurunan rata-rata morfologi abnormal spermatozoa tikus wistar. Adapun morfologi spermatozoa abnormal yang ditemukan pada penelitian ini adalah spermatozoa dengan ekor pendek, ekor putus, kepala dua, serta kepala kecil.

Penelitian ini bertujuan untuk 
mengetahui kualitas spermatozoa yaitu konsentrasi, motilitas, dan morfologi spermatozoa tikus wistar yang dipapari obat nyamuk elektrik berbahan aktif transflutrin.

Konsentrasi spermatozoa tikus wistar yang diberikan paparan obat nyamuk elektrik berbahan aktif transflutrin mengalami kecenderungan penurunan konsentrasi, secara berurutan $\mathrm{P}_{1}$ dan $\mathrm{P}_{2}$ yaitu $54,17 \times 10^{6}$ spermatozoa/ml dan 45,5 x $10^{6}$ spermatozoa/ml, dibandingkan dengan konsentrasi kontrol $\mathrm{P}_{0}$ yaitu 59,25 x $10^{6}$ spermatozoa $/ \mathrm{ml}$. Berdasarkan data tersebut, dapat diamati semakin lama pemaparan obat nyamuk elektrik, semakin konsentrasi spermatozoa cenderung turun (Tabel 1).

Hasil penelitian sebelumnya juga melaporkan penurunan konsentrasi spermatozoa pada pemaparan obat nyamuk turunan pyrethroid lainnya yaitu tetramethrin, permethrin, allethrin pada tikus. ${ }^{4,6}$ Penurunan konsentrasi spermatozoa ini terjadi karena pyrethroid menghambat penyaluran kolesterol ke mitokondria dan menghilangkan konversi subsekuen dan kolesterol menjadi pregnenolon. ${ }^{7}$

Motilitas spermatozoa normal (kategori A dan B) dari tikus wistar yang diberikan paparan obat nyamuk elektrik berbahan aktif transflutrin mengalami kecenderungan penurunan presentase motilitas, secara berurutan pada $\mathrm{P}_{1}$ dan $\mathrm{P}_{2}$ yaitu $40 \%$ dan $35 \%$, dibandingkan dengan kontrol P0 yaitu 45\%. Hasil sebaliknya didapatkan pada motilitas spermatozoa abnormal (kategori C) tikus wistar yang mengalami kecenderungan kenaikan presentase, secara berurutan $\mathrm{P}_{1}$ dan $\mathrm{P}_{2}$ sebanyak $60 \%$ dan 65\%, dibandingkan dengan kontrol $\mathrm{P}_{0}$ sebanyak 55\%. Berdasarkan data tersebut, dapat diamati semakin lama pemaparan obat nyamuk elektrik berbahan aktif transflutrin, semakin menurun presentase motilitas spermatozoa normal serta semakin naik presentase motilitas spermatozoa abnormal. Pengamatan lebih lanjut didapatkan penurunan presentase pada motilitas spermatozoa kategori A, sedangkan motilitas kategori B dan C terjadi kecenderungan kenaikan presentase (Tabel 2). Hasil ini menyarankan bahwa setelah pemaparan obat nyamuk elektrik berbahan aktif transflutrin sebagian spermatozoa dengan motilitas normal berubah menjadi abnormal, secara spesifik perubahan presentase motilitas spermatozoa normal terjadi pada spermatozoa dengan kategori A yang berubah menjadi kategori motilitas spermatozoa normal lainnya yaitu kategori $\mathrm{B}$ ataupun berubah menjadi motilitas spermatozoa abnormal yaitu kategori C.

Motilitas spermatozoa tikus wistar kelas A dalam penelitian ini mengalami penurunan karena energi untuk motilitas spermatozoa disediakan dalam bentuk adenosin trifosfat yang disintesis oleh mitokondria pada bagian ekor. Sehingga apabila terjadi kerusakan pada membran mitokondria akan dapat mengganggu motilitas spermatozoa. Stres oksidatif berperan sebagai mediator kerusakan pada membran plasma, sehingga mengurangi fungsi spermatozoa. Transflutrin akan menyebabkan timbulnya radikal bebas yang akan memicu terjadinya stres oksidatif, sehingga akan menyebabkan kerusakan membran mitokondria dan menurunnya motilitas pada spermatozoa. ${ }^{6}$ Hasil penelitian sebelumnya juga melaporkan penurunan motilitas spermatozoa pada pemaparan obat nyamuk turunan pyrethroid lainnya yaitu tetramethrin, permethrin, allethrin pada tikus wistar. ${ }^{4,5,6}$

Morfologi spermatozoa normal tikus wistar yang diberikan paparan obat nyamuk elektrik berbahan aktif transflutrin mengalami kecenderungan penurunan presentase morfologi spermatozoa normal, secara berurutan $\mathrm{P}_{1}$ dan $\mathrm{P}_{2}$ yaitu $51 \%$ dan $22 \%$, dibandingkan dengan morfologi spermatozoa normal dari kontrol $\mathrm{P}_{0}$ yaitu 75\% (Tabel 3). Hasil sebaliknya didapatkan pada morfologi spermatozoa abnormal tikus wistar yang mengalami kecenderungan kenaikan presentase, secara berurutan $\mathrm{P}_{1}$ dan $\mathrm{P}_{2}$ sebanyak $49 \%$ dan $78 \%$, dibandingkan dengan morfologi 
spermatozoa normal dari kontrol $\mathrm{P}_{0}$ sebanyak 25\% (Tabel 4). Berdasarkan data tersebut, dapat diamati semakin lama pemaparan obat nyamuk elektrik, semakin menurun presentase morfologi spermatozoa normal serta semakin naik presentase morfologi spermatozoa abnormal.

Hasil ini menyarankan bahwa setelah pemaparan obat nyamuk elektrik berbahan aktif transflutrin sebagian spermatozoa dengan motilitas normal berubah menjadi abnormal. Hasil penelitian pada transflutrin ini sesuai dengan hasil penelitian sebelumnya pada pemaparan obat nyamuk turunan pyrethroid lainnya yaitu allethrin yang melaporkan adanya beberapa kelainan morfologi spermatozoa yaitu spermatozoa berekor pendek dan berkepala kecil serta spermatozoa tanpa ekor. ${ }^{4}$ Pada penelitian menggunakan turunan pyrethroid lainnya yaitu permethrin dilaporkan tidak ada perubahan morfologi spermatozoa yang signifikan secara statistik. $^{6}$

\section{SIMPULAN}

Pemaparan obat nyamuk elektrik berbahan aktif transflutrin menyebabkan penurunan kualitas spermatozoa yang terdiri atas penurunan konsentrasi spermatozoa, penurunan motilitas spermatozoa dan penurunan morfologi spermatozoa normal. Penelitian lebih lanjut dengan menggunakan jumlah hewan coba yang lebih banyak diperlukan untuk mendapatkan hasil yang bermakna secara statistik. Adapun keterbatasan dari penelitian ini adalah terbatasnya jumlah hewan coba yaitu tikus wistar yang disebabkan terbatasnya pasokan tikus wistar yang sesuai dengan kriteria penelitian selama waktu penelitian, selain adanya keterbatasan dana.

\section{DAFTAR PUSTAKA}

1. WHO specifications and evaluations for public health pesticides. (cited 2015 jan 22). Available from: http://www.who.int/whopes/quality/Tra nsfluthrin_eval_only_Nov2006.pdf

2. Kurniati R, Aryani R, Wati L. Pengaruh pemaparan pralahir obat nyamuk elektrik yang berbahan aktif dallethrin terhadap fetus mencit (Mus musculus L). Mulawarman Scientifie. 2012;11(2):175.

3. Aryani R, Kurniati R, Rahmawati S. Pengaruh pemakaian obat antinyamuk elektrik berbahan aktif d-allethrin terhadap sel darah mencit (Mus musculus L). Bioprospek. 2011;8(11):30-1.

4. Christijanti W, Utami NR, Iswara A. Efek pemberian antioksidan vitamin $\mathrm{C}$ dan $\mathrm{E}$ terhadap kualitas spermatozoa tikus putih terpapar allethrin. Biosaintika. 2010;2(1):18-26.

5. Sakr SA, Azab AE. Effect of Pyrethroid Inhalation on Testis of Albino Rat. Pakistan Journal of Biological Sciences 2001;.4:498-500

6. Zhang $S$, Ito $Y$, Yamanoshita $O$, Yanagiba Y, Kobayashi M, Tya K, et al. Permethrin may disrupt testosterone biosyntesis via mitochondrial membrane damage of leydig cells in adult male mouse. The Endocrine Society. 2007;148:3941-9.

7. WHO Laboratory manual for the examination of human semen and spermcervical mucus interaction (Fourth Edition), Cambridge : Cambridge University Press,1999

8. Widodo FT. Hubungan antara jumlah leukosit dengan motilitas sperma pada hasil analisa sperma pasien infertilitas di RSUP DR Kariadi Semarang [laporan akhir penelitian]. [Semarang] Universitas Diponegoro .2009. p.5-9.

9. WHO Laboratory Manual for the examination and processing of human semen (Fifth Edition) [cited 2014 Sep 27] Available from: http://whqlibdoc.who.int/publications/2 010/9789241547789_eng.pdf. 